\title{
Publicity and Its Uses. Lost Books as Revealed in Newspaper Advertisements in the Seventeenth-Century Dutch Republic
}

\author{
Arthur der Weduwen and Andrew Pettegree
}

The first weekly serial digest of news appeared in Strasbourg in 1605. This weekly Relation, the work of a bookseller who had until this point run his own manuscript news service, is widely acknowledged as the first printed newspaper. Rather as with the invention of printing one hundred and fifty years before, this novelty found an eager public. Within twenty years a number of cities in Germany and the Low Countries had their own titles; by 1650 at least 50 towns had established a paper, sometimes competing services, and increasingly published twice or three times a week. ${ }^{1}$ Experiments in newspaper publishing were also undertaken in France (the Paris Gazette), England, Sweden and, more fitfully, in several Italian states. ${ }^{2}$ But, as had also turned out to be the case with the invention of printing, this revolution was based on distinctly insecure foundations. The proprietors of these new ventures found it hard to make the economics add up.

Here lay the dilemma. The previously exclusive manuscript services could charge a premium rate, so high indeed that a dozen subscribers could ensure a decent living. ${ }^{3}$ A newspaper, however, was generally sold for a couple of pence an issue, the same as the pamphlet on which it was modelled. Even if several hundred copies of each issue could be disposed of, when the expense of printing and newsgathering were taken into account it was virtually impossible to cover costs from sales alone. To avoid bankruptcy, therefore, publishers faced a stark choice. Either they must rely on discreet subsidies from the local

1 Else Bogel \& Elgar Blühm, Die deutschen Zeitungen des 17.Jahrhunderts. Ein Bestandverzeichnis (2 vols., Bremen: Schünemann Universitätsverlag, 1971); Nachtrag (Munich: Saur, 1985).

2 On the Paris Gazette, Stéphane Haffemayer, L'information dans la France du XVIIe siècle: La Gazette de Renaudot de 1647 à 1663 (Paris: Champion, 2002). On England see Folke Dahl, A Bibliography of English Corantos and Periodical Newsbooks, 1620-1642 (Stockholm: Almqvist \& Wiskell, 1953). Nina Lamal is now embarked on a survey of the far less well known Italian papers: Late with the news. Italian engagement with serial news publications in the seventeenth century (1639-170o) (forthcoming Leiden: Brill, 2018).

3 Andrew Pettegree, The Invention of News (London: Yale, 2014). 
authorities (which many of them did), or they needed to find a new source of income. This was the genesis of the move - tentative at first - to include along with the news a number of paid advertisements. ${ }^{4}$

There was little precedent for this in the first age of print; it required a conceptual leap for publishers both to see the opportunity and to seize it. ${ }^{5}$ Within a century, however, advertising would be the essential financial underpinning of a rapidly expanding industry, and an important contribution to the development of a free press. In the long term advertising would play a crucial, perhaps the decisive role in liberating newsmen from dependence on a patron or subservience to the government.

It is hardly surprising that the first sustained experiments with the new potential of advertising were undertaken in that most commercial of seventeenth-century societies, the Dutch Republic. Here advertisements quickly became a ubiquitous feature of the press. ${ }^{6}$ By 1619 Amsterdam supported two weekly newspaper titles. ${ }^{7}$ As far as we can tell, the first advertisements appeared shortly thereafter, in 1621 . In the early years neither paper survives in a continuous run; indeed, for some years in the 1620 s we can trace only a few stray issues. But as the years went by the papers survive in far greater numbers, and more issues carry one or more advertisements. Overwhelmingly, they advertised other products of the printing press: illustrated broadsheets, engravings and books. For the years between 1621 and 1650 , the present authors have documented over 1,300 newly published books offered for sale in the two major Amsterdam papers, joined in the 1640 os by other new ventures and the first mid-week editions. These advertisements shed fascinating light on the

4 For the critical role played by advertising in the periodical press see particularly R.M. Wiles, Freshest Advices. Early Provincial Newspapers in England (Columbus: Ohio State University Press, 1965).

5 On the early history of book advertising see Graham Pollard and Albert Ehrman, The Distribution of books by Catalogue from the Invention of Printing to A.D. 1800 (Cambridge: Roxburghe Club, 1965). Lotte Hellinga, 'Sale Advertisements for Books Printed in the Fifteenth Century', in Robin Myers, Michael Harris and Giles Mandelbrote (eds.), Books for Sale. The Advertising and Promotion of Print since the Fifteenth Century (London: British Library, 2009), pp. 1-25.

6 This phenomenon has been noted by various scholars; see most importantly Willem Pieter Sautijn Kluit, 'De Amsterdamsche Courant', Bijdragen voor Vaderlandsche Geschiedenis en Oudheidkunde, Nieuwe Reeks, Vijfde Deel (1868), pp. 220-221 and Folke Dahl, 'Amsterdam Earliest Newspaper Centre of Western Europe', Het Boek, 25, 3 (1939), p. 183.

7 The whole history of newspaper production in the seventeenth-century Low Countries is now surveyed in Arthur der Weduwen, Dutch and Flemish Newspapers of the Seventeenth Century, 1618-1700 (Leiden: Brill, 2017). 
workings of what had become Europe's most sophisticated book industry: what was sold, what has survived, and crucially, what has been lost. ${ }^{8}$

\section{Jansz and van Hilten}

When Johann Carolus published the first print edition of his weekly Relation in 1605 , there were no clear rules for business success. Some of the newspapers established in imitation of Carolus closed in less than a year, or after just a few issues. But if anywhere in Europe offered the prospect of success, it must have been Amsterdam. Unusually, two papers sprung up here at much the same time, Caspar van Hilten's Courante uyt Italien, Duytslandt, \&cc., and the Tijdinghen uyt verscheyde Quartieren of Broer Jansz. Equally singular was the fact that both were successfully maintained for more than forty years. ${ }^{9}$

Amsterdam was, of course, an almost ideal market. By 1620 this was a thriving (and fast expanding) city of at least 100,00o inhabitants, offering a large potential readership among its prosperous mercantile and bourgeois population. It was also one of the largest centres of the international book trade. This was a market in which both newspaper publishers were well entrenched. Broer Jansz was already an experienced publisher, active since at least 1603, when he specialised in small pamphlets on contemporary events: he was, in this sense, already a veteran newsman. In later years he would reinvest the profits from these works and his newspaper in more ambitious projects. Jan van Hilten, who succeeded his father Caspar in control of the business in 1623, also branched out into other forms of publishing. ${ }^{10}$ This was a sensible insurance policy against deterioration in the newspaper trade, always possible if new competitors entered the market, or if the local authorities took offence at a particular story and closed down the press. The most successful newspaper publishers around Europe were always those who published a paper as part of a more diverse portfolio of publications.

8 The material used in this paper is drawn from Arthur der Weduwen and Andrew Pettegree, News, Business and the Birth of Modern Advertising. Advertisements and Public Announcements in Dutch and Flemish Newspapers, 1620-1672 (forthcoming Leiden: Brill, 2018).

9 The early survey of these two papers is Folke Dahl, Dutch Corantos 1618-1650:A Bibliography (Göteborg, 1946). Der Weduwen, Dutch and Flemish Newspapers adds further copies not known to Dahl.

10 There are useful biographies in M.M. Kleerkooper and W.P. van Stockum, De Boekhandel te Amsterdam, voornamelijk in de 17e Eeuw (The Hague: Martinus Nijhoff, 1914-1916). 
Some of the books that Jansz and van Hilten advertised in their papers were their own publications; not infrequently, interestingly, Jansz also advertised in van Hilten's paper. ${ }^{11}$ This was not a relationship of cut-throat competition; sensibly enough, in places where newspapers could not establish a local monopoly they seldom chose to compete on price. From their early days, however, Jansz and van Hilten also took advertisements from other publishers: first in Amsterdam, then from cities further afield.

The Dutch Republic was Europe's most vibrant economy, a wonder of its age. Amsterdam was the international metropolis, but the strength of its economy lay largely in the integration of Amsterdam with a network of other cities throughout the province of Holland and beyond. Places like Leiden, Rotterdam and Haarlem were substantial cities in their own right; none, curiously, immediately spawned their own newspaper. The two Amsterdam newspapers seem to have served this market as well: Broer Jansz and Jan van Hilten published what were to all intents and purposes national newspapers. That this was so has now been definitively demonstrated by Arthur der Weduwen, largely on the basis of an analysis of their advertisements. ${ }^{12}$ Once booksellers in Vlissingen, Leeuwarden or Groningen began to advertise their books with Jansz and van Hilten, one can reasonably infer that the Amsterdam papers were circulating widely in these places; a conclusion that is supported by surviving account books and booksellers' receipts. ${ }^{13}$

By this time the form of the advertisements had also become clearly established. Both Amsterdam papers were published on a single half-sheet, printed on both sides. This allowed a remarkably large amount of text to be crammed into the paper (the pamphlet format used for news serials in Germany and elsewhere in Europe was far more wasteful of space and paper). Advertisements were always placed at the very end of the text, at the bottom of the second column on the reverse side. Here they were well placed close to the domestic

11 Such as in Courante uyt Italien, Duytslandt, \&c. (CID) no. 22 (28.05.1639); CID no. 38 (22.09.1640); CID no. 14 (06.04.1641); CID no. 36 (07.09.1641); CID no. 29 (19.07.1642).

12 Arthur der Weduwen, 'Booksellers, newspaper advertisements and a national market for print in the seventeenth-century Dutch Republic', forthcoming in Shanti Graheli (ed.), Buying and Selling (Leiden: Brill, 2018).

13 See Henk Borst, 'Van Hilten, Broersz. en Claessen. Handel in boeken en actueel druwkerk tussen Amsterdam en Leeuwarden rond 1639', De zeventiende eeuw, 8 (1992), pp. 132-135, Henk Borst, 'Broer Jansz in Antwerpse ogen: de Amsterdamse courantier na de slag bij Kallo in 1638 neergezet als propagandist', De zeventiende eeuw, 25, 1 (2009), p. 83 and Otto Lankhorst, 'Newspapers in the Netherlands in the seventeenth century', in Brendan Dooley and Sabrina Baron (eds.), The Politics of Information in Early Modern Europe (London: Routledge, 2001), p. $15^{2}$. 
news, always relegated to last place after the foreign despatches. The advertisements and domestic reports could also be expanded if foreign news was thin, or held back if foreign news was abundant.

The Tijdinghen uyt verscheyde Quartieren of 23 June 1635 was fairly typical. This contained two advertisements, from different Amsterdam publishers. Jan Evertsz Kloppenburch presented a new translation of Philippe Du PlessisMornay's history of the papacy. ${ }^{14}$ Marten Jansz Brandt offered a controversial work by the Contra-Remonstrant author Jacobus Trigland (1583-1654), refuting a Remonstrant tract entitled De War-Religie [The Confused Religion].15 Both, it should be noted, were substantial tomes. The cost of the advertisement could be set against the expectations of substantial profit from sales. Brandt had also taken the precaution of placing the same advertisement in the other Amsterdam paper, van Hilten's Courante uyt Italien. This, again, was not uncommon.

Both these works can be easily identified: they survive in four copies each. More interesting from our point of view are the advertisements carried in the Tijdinghen uyt verscheyde Quartieren on 6 October of that same year. ${ }^{16}$ Again there were two advertisements. Broer Jansz took advantage in the space of his own paper to advertise two books, The Way to Heaven and The Way to Salvation, which he was publishing in association with the Gorinchem publisher Adriaen Helmichsz. These books, authorised by the Synod of Goes in 1620, were apparently being reissued. But there are no surviving copies either of these editions or the 1620 originals. ${ }^{17}$ In the same paper Jan Evertsz Kloppenburch advertised Het groote Matery-boeck, a primer of different scripts in several different language styles. This too, cannot be traced to a surviving copy. ${ }^{18}$

\section{Publication and Loss}

How common is this phenomenon? In the course of an intensive year of work on the first generation of Dutch newspapers, the authors of this paper have documented something over 1,300 advertisements offering new books for sale in Dutch newspapers in the years between 1621 and 1650 . Around $68 \%$ of them

\footnotetext{
14 USTC 1033126.

15 USTC 1013316.

16 Tijdinghen uyt verscheyde Quartieren (TVQ) no. 40 (o6.10.1635).

17 USTC $1512382,1512383,1512384$ and 1512385 . In fact, altogether few works attributed to Adriaen Helmichsz survive; between 1608 and 1635 only 23 works are extant.

18 USTC 1512381.
} 
have successfully been matched with a surviving book published at the correct date, and by the advertised publisher. This still leaves over 400 books, one third of the total, for which a surviving copy has not yet materialised: lost books. ${ }^{19}$

This work has been greatly assisted by the quality of the original data. Almost all the books advertised in the newspapers are described with their accurate published title: since the purpose is to encourage retail sales, this is something about which the client would have likely to have been very particular. The advertisement also includes the name of the publisher; sometimes the format, and sometimes also further valuable incidental material, such as the name of the translator. Since advertisements were almost always only placed for newly published works, this means we have all the bibliographical data necessary - title, publisher, date - to match an advertised book with the original. Occasionally a book published in the latter months of one year will be advertised for sale in January or February of the next; occasionally a book will be advertised in December and then only appear in the new year. But these are relatively rare occurrences (and more likely when the book is published outside Amsterdam). Usually the placing of the advertisement was remarkably punctual: it was, in any case, relatively easy for Amsterdam publishers to send a boy round to the newspaper office, with the details (or a proof sheet of the title-page) and the necessary fee. Both Jansz and van Hilten had premises close to the Bourse and the Dam, the city's commercial centre, where many of the city's printers also had their workshops.

For the purpose of this study all of this advertising data has been compared with an analytical list of all books published in the Low Countries between 1601 and 1650 . Most of these books are also listed in the Short Title Catalogue Netherlands, but by no means all. A quite significant number of these advertisements have been matched only to copies found in libraries outside The Netherlands. Even after this intensive search a fair number of books advertised are not accounted for, presently around a third of the total. Some will no doubt turn up; others will remain lost books.

This is hardly surprising, as the other studies in this collection make abundantly clear. But the scale of the loss is still very striking. For we are not dealing here with a representative cross section of all the books published in the Low

19 The authors matched the advertised books against a master list of books published in the Low Countries between 1601-1650. This master list incorporates both books listed in the STCN, a systematic survey of library holdings in the Netherlands, and data gathered from other collections around the world. The work involved both authors in a double blind process of matching and verification. The list of matched and lost books will be set out in full in Der Weduwen and Pettegree, News, Business and the Birth of Modern Advertising. 
Countries in these years. Publishers only advertised if this was worth their while: but they were as likely to advertise substantial tomes, where moving another fifty copies could make all the difference between healthy profits and a substantial loss, as small pamphlets. Some of the works advertised are quite small, but a high proportion of these are the newspaper proprietors' own pamphlets. Classes of printed matter that have suffered the highest rates of attrition, such as broadsheet ordinances and other ephemera, do not appear at all in the newspaper advertisements.

So we are often dealing here largely with classes of work that survive well; and yet as many of a third of them cannot be traced to a surviving copy. These advertisements, surveyed in the course of an investigation undertaken for a quite different purpose, have quite unexpectedly revealed a treasure trove of information on a lost part of the seventeenth-century book market.

What then was the character of these lost books - which books of those advertised were most likely to have disappeared altogether? To answer that question we have first to identify more closely that sub-section of the book market for which publishers were likely to go to the extra expense of placing an advertisement in the newspapers. These books were, broadly speaking, most likely to fit into one of four categories: big projects (that is large, expensive books requiring heavy up-front investment); best sellers; the accoutrements of worship (Bibles, psalters and prayer books); and professional handbooks.

News books, interestingly, do not feature particularly strongly in advertisements. The exception to this rule was broadsheet engravings of contemporary events. These, like maps, had relatively high initiation costs, and clearly appealed to the same class of purchaser as were likely to have taken a subscription to one or other of the newspapers. Indeed, for those following the abbreviated, fact-loaded reports of foreign events in a newspaper a map or atlas was presumably something of a necessity. Also exceptionally popular in the Dutch Republic (and, for that matter, in the Southern Netherlands) were maps and town plans showing the progress of a siege or battle. Naturally they sold particular well in the wake of a victory, though long sieges also called forth published engravings showing the disposition of the besieging forces; these could be updated and reissued as the siege went on. ${ }^{20}$ For our purposes these pose particular bibliographical challenges, as they were often described in the papers in very general terms: such as the map of the siege of Breda offered by

$20 \quad$ Europische Dingsdaeghs Courant (EDC) no. 43 (24.10.1645), Ordinarise Middel-weeckse Courante (омwC) no. 45 (o7.11.1645), Ordinaris Dingsdaegsche Courante (ODC) no. 49 (05.12.1645), for maps of the siege of Hulst offered for sale by three different Amsterdam publishers. 
the Amsterdam publisher/engraver, Claes Jansz Visscher, in the Tijdinghen uyt verscheyde Quartieren of 19 November $1624 .{ }^{21}$ Self-evidently, broadsheets do not have a title-page, and in the case of engravings often not even a title or heading. It is therefore more than usually challenging to match them to existing examples: very likely some will be lost.

These patriotic engravings were extremely popular with the buying public, and a lucrative part of the publishing trade. Nor did publishers have to rely exclusively on sales for their reward. Two months before his map of the siege of Breda, Claes Jansz Visscher had offered for sale an illustrated map of the Bay of Todos Santos and of the conquest of the city of Salvador de Bahia in Brazil. This was not an initiative of his own, but published with the sponsorship of the West Indian Company. ${ }^{22}$ The attempt to challenge the Spanish Empire in Latin America was a controversial venture in Dutch political circles, with as many enemies as friends, particularly among the sponsors of the more entrenched Dutch East India Company. Here it did no harm to give the buying public a nudge towards greater enthusiasm for this feat of Dutch arms. On other occasions the States General would send the publisher of a particularly popular or effective patriotic print a cash reward. ${ }^{23}$ This provided a further substantial inducement for publishers to try their hand in what was a very busy part of the market; leading engravers like Claes Jansz Visscher were very much in demand.

The books we have described as big projects also by and large survive. This, again, makes very good sense. Publishers had invested heavily to bring them to the market. They were costly to purchase, and once sold tended to make their way onto the shelves of libraries, where they had a very good chance of survival. It is worth reflecting at this point that Dutch libraries have suffered relatively little from the catastrophic losses that have afflicted other book cultures through pillage, bombardment or deliberate destruction. ${ }^{24}$ Many of the books in this category survive in relatively large numbers. They are not, for that reason, without interest. Often they represented a considerable investment on the

21 This is quite possibly USTC 1515493: Cort verhael, ende perfecte Afbeeldinge der Stad ende Belegeringe van Breda, Midtsgaders het Leger van den Doorl: Prince van Orangien, tot Ontset der voorsz Stad. Claes Jansz Visscher advertised at least 17 times in Amsterdam papers between 1621 and 1645 .

22 Probably Ustc 1116099. See also Michiel van Groesen, 'A Week to Remember: Dutch Publishers and the Competition for News from Brazil, 26 August-2 September 1624', Quaerendo, 40 (2010), pp. 26-49.

23 As with Broer Jansz, for a celebratory engraving of the Twelve Years' Truce entitled Pyramis Pacifica in 1609 . N. Japikse, et al. (eds.), Resolutiën der Staten-Generaal van 1576 tot 1609, Veertiende Deel (The Hague: Martinus Nijhoff, 1970), p. 914.

24 See chapters twenty-one to twenty-three in this volume. 
part of a publisher who would normally have been associated with far more modest projects. In 1637, for instance, the Enkhuizen publisher Volchardt Jansz Camerlingh offered for sale Grondige ende clare Verthooninghe van het onderscheyt in de voornameste hooft-stucken der Christelijcker Religie [A clear and fundamental explanation of the differences in the major parts of the Christian Religion], written by two local ministers. ${ }^{25}$ This was a substantial work of almost one thousand pages, and one of only three books known to have been published in Enkhuizen that year. Also in 1637, the Groningen publisher Hans Sas offered for sale a major legal text, Anthoni Matthaeus' Collegia juris Sex. ${ }^{26}$ This was a demanding assignment for a provincial press, which Sas handled by dividing the work into seven segments. In both this case and that of Camerlingh's Clear explanation this single work must have occupied the workshop for the best part of the year; indeed, Camerlingh in Enkhuizen took the sensible precaution of sharing the costs with another Enkhuizen publisher, who also offered it for sale. ${ }^{27}$ It is no wonder that, having invested so heavily, the publishers thought it worth their while to pay the small additional sum to bring their work to the attention of a national public.

\section{Best Sellers}

Marten Jansz Brandt was a publisher of a very different sort. ${ }^{28}$ The owner of an exceptionally busy and successful publishing house, Brandt was a perennial presence in the advertising columns of the newspapers. Generally he offered his stock in trade: religious best sellers. Usually he would advertise one or two books, but the Courante uyt Italien of 16 September 1643 offered new editions of no fewer than eight books, all written by the Amsterdam preacher and prolific author Roelof Pietersz (Rudolphus Petri) (1586-1649).

D. Roelof Pietersz, Het Lof Jesu Christi onses Heeren, already published in 1643; Item, Het Lof der kercke Jesu Christi, already published in 1643; Item, 't Lof des Woordts Godts, ofte der H. Schrifture, published in 1640; Item, Scherm ende Schilt der kinderen Godes, an explanation of psalm 91; Item, De Spiegel der Barmhertigheyt en Gerechtigheyt Gods, in het vergeven en straffen der sonden; Item, De Enge poorte, ofte de Wegh der Saligheyt;

\footnotetext{
25 CID no. 38 (19.09.1637).

26 TVQ no.43 (24.10.1637).

27 TVQ no. 39 (26.og.1637).

28 There is basic biographical data in Kleerkooper and van Stockum, Boekhandel, pp. 103, 1191-3.
} 
Item, Eenige korte gulden Regelen eenes heyligen levens; Item, Den Evangelischen Arendt (all enlarged and reviewed, and improved according to the new translation of the Bible) (all Amsterdam, Marten Jansz Brandt). ${ }^{29}$

Such a large advertisement was not unprecedented; in 1639 Willem Jansz Blaeu even took space in the Tijdinghen uyt verscheyden Quartieren to advertise nineteen books. ${ }^{30}$ But on that occasion Blaeu was clearing old stock: here, as was almost invariably the case, Brandt was advertising new publications. Brandt knew his market. He had taken eight of his most successful publications and revised them to conform to the recently published new translation of the Bible (the Statenbijbel). All of them had done well for him, and would continue to do so. Brandt had published the Scherm ende Schilt der kinderen Godes already in 1631 and 1636 , and would do so again in $1644 .{ }^{31}$ De Spiegel der Barmhertigheyt en Gerechtigheyt Gods, in het vergeven en straffen der sonden was published in $1628,1632,1640$ and 1644 , in addition to this edition. ${ }^{32}$ For Eenige korte gulden Regelen eenes heyligen levens there are editions recorded for 1632, 1634, 1638 and 1641, all by Brandt. ${ }^{33}$ Den Evangelischen Arendt he published in 1637, 1639 and $1646 .{ }^{34}$ Interestingly, none of the eight editions advertised here in 1643 can be linked to a surviving edition.

This, indeed, may only be the tip of the iceberg. We can see that Roelof Pietersz's Het Lof Jesu Christi onses Heeren is described as the second edition published in this same year, 1643. In the case of the De Enge poorte, ofte de Wegh der Saligheyt Brandt will republish this again in 1646 , where it is described as the seventh edition. ${ }^{35}$ None of the previous editions have yet been traced. ${ }^{36}$ This sort of phenomenon is not at all unusual. In 1642 Brandt published Het Lof des Heeren, described in the advertisement in the Tijdinghen uyt verscheyde Quartieren as the ninth edition. ${ }^{37}$ This edition

\footnotetext{
29 This is a paraphrase of the original Dutch.

$30 \quad$ TVQ no. 36 (03.09.1639).

$31 \quad 1631$ (USTC 1013422), 1636 (1013433), 1644 (1013421), all published by Brandt.

32 This lost edition USTC 1515575. 1628 (1030778), 1632 (1020976), 1640 (1013633), 1644 (1013875).

33 USTC 1515577. 1632 (USTC 1013325), 1634 (1013324), 1638 (1016678), and 1641 (1021123), all for Brandt.

USTC 1515578. 1637 (USTC 1013433), 1639 (1013622) and 1645 (1030787). A second part was published in 1645 (STC 1013880) and a third part in 1650 (USTC 1014870).

35 USTC 1013943.

36 Though the same title is used for an earlier work by Eduard Poppius (1576-1624). See USTC 1010725,1010728 .

USTC 1019080.
} 
does survive, but we can document only one other of the previous eight. Two years later he offered an edition of Charles Drelincourt's Gebeden en Meditatien om sich te bereyden tot het H. Avondtmael. ${ }^{38}$ Drelincourt (15951669) was a popular French preacher, and this was the sixth edition of a translation by the Beverwijk preacher, Gilles van Breen. This edition does not survive, and the only ones that do are an edition of 1639 , and a further subsequent edition of $1649 \cdot{ }^{39}$

The information we can extract from these notices also helps address one significant methodological question. It is legitimate to pose the question whether newspaper notices are always advertising freshly published editions. How when a publisher was advertising a text in 1644 can one be sure that this was a new edition, and not an edition published in 1642 and known from a surviving copy? In the case of these religious best-sellers we can be pretty confident that this was not the case. There is useful corroborative evidence in this respect from the publication history of Tranen Christi [The Tears of Christ], another work of the prolific Roelof Pietersz. In January 1645 Marten Jansz Brandt advertised a new issue which he described as the third edition. ${ }^{40}$ This must have sold well, because in April he was back with a fourth edition. Owners of the previous edition were wooed with the promise that this edition was 'improved and enlarged by half by the author'.41 Claims of this sort were frequently made by publishers, and the third edition had been accompanied by a similar claim. Neither of these survives: in fact, the only edition known from this year (again published by Brandt) is described on the title-page as a fifth edition. ${ }^{42}$

So Brandt, we now know, published three editions of this book in one year. If this was so, the reconstruction we offer of these religious bestsellers may still represent a considerable understatement of the extent of this market. None of these books has the longevity or success of the Confessionale whose extraordinary publishing history is reconstructed in this volume by Rosa Marisa Borraccini. ${ }^{43}$ But collectively these books add up to a whole lost world of popular religious classics; often the advertisements in the Amsterdam newspapers offer the only hint of their survival.

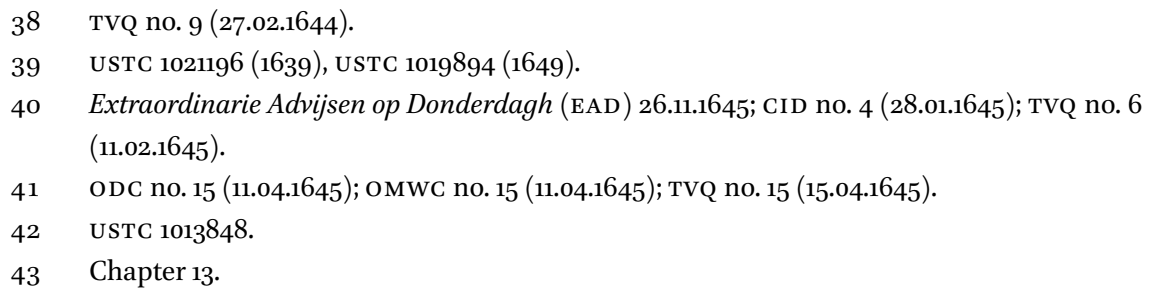




\section{A People of the Word}

In the seventeenth-century Dutch Republic there was consistent demand for new editions of the Bible, psalters and prayer books of various descriptions. Amsterdam, as is well known, was one of Europe's major centres of Bible production, and publishers frequently used the newspapers to advertise their new editions.

This proliferation of new publications, from stately folio family Bibles to a variety of small pocket-sized formats, poses real challenges to bibliography. The small editions in particular are often incorrectly catalogued by holding libraries. Editions in $16 \mathrm{mo}$ and $32 \mathrm{mo}$ are often confused, as are the more infrequent editions in $12 \mathrm{mo}$ or $24 \mathrm{mo}$. The result is that editions described in library catalogues in these formats cannot with authority be described as separate editions. Older printed catalogues are often even more imprecise, stipulating a format, quarto, octavo or smaller, based more on shelving practice than physical examination of the copy. One distinguished bibliographer, Paul Valkema Blouw, had so little confidence in such catalogues that he decided to exclude any mention of format from the entries in his Typographia Batava, the bibliography of northern Netherlandish imprints between 1541 and $1600 .{ }^{44}$

Here the advertisements can play a decisive role, since it can be assumed that publishers giving notice of new editions knew the formats of their own works very precisely. This was especially the case as publishers often offered a choice of several formats in the same advertisement. Thus in the Tijdinghen uyt verscheyde Quartieren of 24 July 1638 , an advertisement also placed in the following week's Courante uyt Italien, were offered for sale:

Het Testamentjen, 12mo, according to the new translation ordained by the States General; the same Testamentjen, 24mo, with a psalmboeck (both The Hague, the widow and heirs of Hillebrant Jacobsz van Wouw, Leiden, David Jansz van Ilpendam, and Paulus Aertsz van Ravesteyn).

The duodecimo edition, also advertised in the Courante uyt Italien of $17 \mathrm{July}$, is known from surviving copies; but the 24 mo edition cannot currently be traced. ${ }^{45}$

This may at first sight seem rather surprising, as Bibles were cherished possessions, and they have certainly survived in very large numbers. But although

Paul Valkema Blouw, Dutch Typography in the Sixteenth Century, ed. Tom Croiset van Uchelen and Paul Dijstelberge (Leiden: Brill, 2013). 
family Bibles were passed down the generation (and often inscribed with valuable genealogical information), the Bible text was also very heavily used. Many families would own several, with different formats for consultation and study, travel, taking to church or communal family prayers. New copies were always needed as older ones wore out, children grew to adulthood and new family units were formed.

Publishers followed the market with acute attention; one obvious need was for compendia that joined together two or more of the religious staples in everyday use. The Courante uyt Italien of 28 November 1643 carried two such advertisements: a combined Psalter and catechism published by the Leiden printer Paulus Aertsz van Ravesteyn, and an edition of the New Testament, "with the psalms and songs along with music-notes". Both were in very small formats, the Leiden compendium in an almost impossibly tiny 48mo. In July 1643 Ravesteyn had already advertised a combined New Testament and Psalter in $24 \mathrm{mo}$ and a Psalter in $32 \mathrm{mo}$; the November compendium was a logical extension of this obviously successful publication strategy. ${ }^{46}$ As Ravesteyn was part of the consortium responsible for the publication of the first Statenbijbel in 1637, the Bible market was to him a true niche. Other printers sought to take a share of this profitable industry. In 1643 an Amsterdam New Testament, presumably meant for use in church, was also published in 24mo. This was published by a consortium that included the printer of Jan van Hilten's paper, Jan Fredericksz Stam; perhaps he got preferential rates for the advertisement. Neither of the two editions advertised in November survive, nor indeed does an 80 New Testament published by Stam's consortium earlier in the year. ${ }^{47}$

\section{Mechanical Arts}

The publishing and marketing strategies revealed in these advertisements leave us in little doubt that the trade in religious literature was the true bedrock of the industry. Unless a publisher was lucky enough to have a profitable monopoly - for instance for an official body such as the States General, the city of Amsterdam or the University of Leiden - this was the most open market to which they had access, and few ignored it. The trade in religious books was essentially three interlocking markets: the official texts of the church, works of controversy and polemic, and popular devotional works. The smouldering aftershocks of the Remonstrant controversy ensured that works of controversy

46 The 24 mo is USTC 1011871 , and the 32 mo USTC 1514671 .

47 The same association also published a folio Bible: USTC 1029993. 
continued to be published, though they are less frequently advertised in the newspapers than devotional works. Scholars of the Reformation have only recently begun to recognise the importance of this Protestant appetite for devotional literature, characteristically thought of as a Catholic genre. The evidence of the newspapers demonstrates its extraordinary vitality in the Dutch Republic.

For all the towering importance of religious literature, others genres were certainly sufficiently important to feature in the publishers' marketing strategies. We see evidence of the growing importance of a literature of recreation. Curiously, the volumes of romantic tales or chivalric romances that had dominated popular taste in the sixteenth century do not leave much of a trace. What we do see to a quite unexpected degree is the development of a new bourgeois market in music. On 22 December 1644, for instance, Cornelis Leeuw advertised for sale a bumper batch of nine musical texts:

Hollandtsche vreught, with four voices, and an added 'bas-continuo' (вс); the second part of the Hollandtsche vreught, with a BC; Hugo de Groot, Lofsangen op de gheboorte Christi, with three voices; Idem, 't Leven Christi, with three voices; Verrijsenis Christi, with three voices; Hemelvaert Christi, with three voices; Sendinghe van den Heyligen Gheest, with three voices; Hugo de Groot, Christelijcke Ghebeden, with three voices, and a BC; D. Camphuysen, Ses Psalmen, with four voices. ${ }^{48}$

These were books of a rather different character from the elegant part book editions intended primarily for use by professional choirs: indeed, if those part books survive, they do so mostly in collections derived from the court settings in which they were first used. These Dutch books seem primarily intended for use in the home. This may explain the high rate of attrition: none of the books listed above can be traced to a surviving copy. If copies could be located they might shed interesting light on a part of Dutch bourgeois culture presently rather hidden from view. Certainly there is little sign of texts of this sort in the stately but curiously arid depictions of the bourgeois drawing room in the interior landscapes of the Dutch Golden Age.

Before one could enjoy such pleasures one first had to earn one's place. In the mobile but unforgiving commercial culture of the new republic there were plenty who aspired to better themselves, and publishers were keen to give them a helping hand. Almost from the first days of print there had been an important market for works of technical instruction; unsurprisingly, this was

$48 \quad \mathrm{EAD}, \mathbf{2 2 . 1 2 . 1 6 4 4 .}$ 
especially important in the Dutch Republic. Appropriately enough, the competition between authors was fierce. When masters of arithmetic built a successful practice it was natural that they should seek to expand their client base through print, and many did so. The newspapers advertised books of arithmetic written by Willem Bartjens, Daniel van Houcke, H.C. Mots, David Cock van Enckhuysen and Johan Coutereels. Interestingly, these books did not lose their commercial value with the author's death. Willem Bartjens' heirs put out a whole series of new editions after his death in 1638 (the first edition had been published in 1604), and the works of Coutereel also remained popular after he left the scene.$^{49}$ Works of accountancy and book-keeping were also steady sellers. It is interesting to see that even in this period, some centuries after the invention of double entry book-keeping, to advertise that a work followed the Italian method still brought commercial kudos..$^{50}$

Many of these Cijfferboeken and Rekeningen survive, but many more do not. Pored over by inky fingers late into the night, it is no wonder that books of this sort became soiled and needed frequently to be replaced. For tradesmen and merchants seeking to keep up with the latest developments in practice the lure of a new edition was also strong. This was a lucrative market, though for printers these were challenging texts, with tables of figures, diagrams and complex equations. One can note the rather defensive tone in which Hendrick Tjercksz de Vries advertised the second edition of David Cock van Enckhuysen's CijfferKonst, "never before so detailed and clearly explained, corrected of all misprints, improved and enlarged by the author". ${ }^{11}$ Printers kept plugging away, because this was so profitable a niche market, with a double appeal both for use in the school room and for self-instruction. ${ }^{52}$ Also popular in this genre of self-improvement were books giving examples of fine hand-writing, or providing model letters for all occasions, polite, commercial or romantic. Some texts in this genre, as we know from Pre-Revolutionary France, continued to be

49 Johan Coutereels (1594-1631 fl.), seven editions of five different texts between 1610 and 1646.

50 CID no. 48 (01.12.1640): David Cock van Enckhuysen, Het Cort begrijp van't gantsch Italiaens boeckhouden, useful for students but also merchants and accountants, second impression (Amsterdam, Hendrick Tjercksz de Vries). De Vries would publish a third impression in 1641, advertised in CID no. 43 (26.10.1641). Thomas Fonteyn in Haarlem published a competing text on Italian accounting by Jean Belot in 1641: USTC 1018202.

$5^{1} \quad$ TVQ no. 16 (22.04.1645). No copy traced.

52 For example, in the CID of 7 March 1643 the French schoolmaster Samuel Barard advertised his intention to start a school in Alphen, and invites parents to sign up their children in order for them to learn writing, calculations, Italian accounting and the basics of music. 
published for the best part of a century, and in enormous numbers. ${ }^{53}$ The ultimate expression of this spirit of social aspiration was Jan de Brune's (1616-1649) Wetsteen der vernuften, breathlessly advertised by its publisher as "good for all types of people, but especially for those who want to be admired by women and who want to be in the best company". ${ }^{44}$ A popular work of emblematic essays, the Wetsteen was first published in 1644 and went through further editions in $1652,1658,1659$ and 1661.

These practical books found a market all over Europe, but in the Dutch Republic they had a special resonance. Whereas in most competitor societies, France and to a lesser extent England, social elites were fixed, and in Spain wholly ossified, the Dutch had no established aristocracy to set the social tone. The selfperpetuating quasi-aristocracy of the eighteenth century was still some way away: immigration, social mobility and constant striving were the life blood of the new state. This was a part of Europe where self-taught autodidacts could read themselves to a better life. The minimal investment on books of self-improvement must have seemed a reasonable wager on the chance of a glittering future.

\section{Catalogus Universalis}

On 12 November 1639 Broer Jansz placed a very unusual advertisement in his Tijdinghen uyt verscheyde Quartieren:

Broer Jansz, printer at Amsterdam, has the intention henceforth to publish every six months a Catalogue of all the books that are published in this country, as is done at Frankfurt, and will do so for the first time on the first day of January next exactly: he therefore requests all booksellers and printers to furnish him at their expense with the titles of the books printed by or for them this year, all to be entered under their names according to each faculty and language, for the convenience of booksellers, and all book-lovers. ${ }^{55}$

The first edition duly appears in January 1640. Broer Jansz went on to publish fifteen further editions between 1640 and $165^{2}$ in a continuous sequence, at

53 Roger Chartier, 'Sécretaires for the people', in Roger Chartier, Alain Boureau and Céline Dauphin, Correspondence. Models of Letter-Writing from the Middle Ages to the Nineteenth Century (London: Polity Press, 1997), pp. 59-111.

54 TVQ no. 47 (21.11.1643).

55 TVQ no. 46 (12.11.1639). Also published in the Nouvelles de divers Quartiers no. 46 (14.11.1639). 
first twice a year, but from the sixth catalogue at an annual interval. ${ }^{56}$ Here Broer Jansz was imitating on a smaller scale the famous collective catalogues published, since the late sixteenth century, for the Frankfurt Fair. ${ }^{57}$ The title, Catalogus Universalis, and the six monthly intervals envisaged for publication, suggest that Jansz had modelled his venture explicitly on the Frankfurt prototype. The internal structure of the Catalogus Universalis also followed closely that of the Frankfurt catalogues. Books in Latin were arrayed in traditional categories: first theology, followed by jurisprudence, medicine, philosophy and literature. Sometimes history was united with jurisprudence, and the smaller categories incorporated into a miscellaneous list. Books in vernacular languages made up the second half of the catalogue, arranged by language with no further sub-divisions.

Each issue of the Catalogus Universalis contained an average of 150 entries. Almost half were Latin and the rest largely Dutch: other vernaculars made up only $7 \%$ of the total. ${ }^{58}$ We can see from this that the Catalogus Universalis had a very different role in the book trade. Publishers used the newspapers overwhelmingly to advertise books in Dutch: only around $25 \%$ of the advertisements were for Latin titles. We can deduce from this that the two forms of publicity were directed towards different audiences. Publishers clearly saw in newspaper advertising the opportunity to reach a wide potential public, interested mainly in popular religious works, Bibles and technical handbooks. The Catalogus Universalis was expected to circulate among other industry professionals, but also to interest serious collectors both within the Dutch Republic and abroad. We know that collectors and librarians seeking to build a personal or institutional collection used the Frankfurt Fair catalogue in this way. That Broer Jansz's Catalogus Universalis also found an international audience is at least suggested by the present locations of the rare surviving examples of the individual catalogues: Paris, Dublin, Weimar and St Petersburg.

No other Amsterdam publisher sought to emulate Broer Jansz's venture, though some did issue catalogues of their own stock. In June and July 1639 the Utrecht printer Jan van Doorn advertised catalogues of all the Italian and Flemish

$5^{6}$ See here the facsimile edition prepared by H.W. de Kooker, The Catalogus Universalis (Utrecht: H\&S, 1986).

57 The catalogues for the period $1564-1600$ is available as a facsimile reprint: Bernhard Fabian, Die Messkataloge des sechzehnten Jahrhunderts (5 vols., Hildesheim: Olms, 1972-2001).

$5^{8}$ De Kooker, Catalogus, p. 19. 
music books available in his shop. ${ }^{59}$ This seems to have been a specialism of his; when in 1644 the whole stock of his book shop was sold off, this included a considerable number of books in Italian, Spanish and French. This too required a catalogue, duly advertised in the Tïdinghen uyt verscheyden Quartieren. ${ }^{60}$

The 1644 catalogue, frustratingly, does not survive, as it would provide a fascinating window onto the book market in Utrecht, an important provincial city. The newspapers also provide an occasional glimpse of another important developing part of the Dutch book market, book auctions. In the Courante uyt Italien of 16 January 1644 , the guardians of the heirs of the deceased minister Nicolaus Molineus announced the sale of his books, to take place nine days later. As in this case, each of these auctions required a printed catalogue, and these too furnish a remarkable fund of bibliographical data. ${ }^{61}$ There is no doubt that a comprehensive survey of any or all of these sources - the Catalogus, booksellers' stock catalogues and auction catalogues - would provide a tremendous amount of information on the Dutch book world of this period. No doubt it would also provide a valuable new harvest of lost books.

\section{Changing the Guard}

By the late 1630 s Broer Jansz was riding high: not only was he the manager of a large and prosperous firm, his son, Joost Broersz was also a successful publisher, putting out books, advertising in his father's newspaper, and even running a paper of his own, the Ordinaris Dingsdaegsche Courante. ${ }^{62}$ This was quite an achievement, because by the mid-1640s the newspaper market was becoming distinctly crowded. In 1638 François Lieshout had entered the market with a mid-week paper, the Ordinarise Middel-weeckse Courante; since this

\footnotetext{
59 CID no. 26 (25.06.1639) and TVQ no. 28 (09.07.1639).

6o The catalogue was published three months before the planned sale. TVQ no. 9 (27.02.1644). See also EAD 09.06.1644.

61 See especially now Brill's survey of Dutch auction catalogues, Book Sales Catalogues Online: <http://www.brill.com/products/online-resources/book-sales-catalogues-dutch -republic-online>. See also Laura Cruz, The Paradox of Prosperity: The Leiden Booksellers' Guild and the Distribution of Books in Early Modern Europe (New Castle, DE: Oak Knoll Press, 2009) and Bert van Selm, Een menighte treffelijcke Boecken: Nederlandse Boekhandelscatalogi in het begin van de zeventiende eeuw (Utrecht: $\mathrm{H} \& \mathrm{~S}, 1987$ ).

62 Broersz advertised in the TVQ on multiple occasions. See for example TVQ no. 46 (14.11.1637); TVQ no. 12 (21.03.1643); TVQ no. 35 (29.08.1643); and TVQ no. 39 (30.09.1645). In 1639 Joost Broersz started with his own Courante Extra-Ordinaire, but from 1640 he settled permanently with the Ordinaris Dingsdaegsche Courante.
} 
proved very successful, both van Hilten and Joost Broersz responded with their own mid-week ventures. ${ }^{63}$ By 1642 they faced yet another competitor, Mathijs van Meininga, with his thrice weekly paper, the Europische Dingsdaeghs Courant, Europische Donderdaeghs Courant and Europische Saterdaeghs Courant. All but Meininga followed the example of the two pioneers in bolstering their income by taking paid advertising: soon publishers were advertising the same books in three or four different papers.

This multitude of competing papers proved of short duration. By 1647 there is no trace of any of Meininga's newspapers - presumably he had already closed his doors. Even a market as robust as Amsterdam could not sustain so many papers, but perhaps his failure to grasp the importance of advertising contributed to making the paper unprofitable. ${ }^{64}$ The market would develop in the second half of the century in a rather different way, with the establishment at last of sustainable papers in other Dutch towns, most notably Haarlem, The Hague, Utrecht and Leiden. This would pose a new challenge to Amsterdam, but perhaps not as serious as might have been thought. Obviously it allowed inhabitants of these towns to obtain their newspaper closer to home, but Dutch publishers were also adept in exploiting the rage for news among subscribers for whom even a paper published three times a week was insufficient. By staggering days of publication in different cities it became possible to get the best of all worlds: taking several subscriptions allowed the real news hound to create what was in effect a daily news service. ${ }^{65}$

The advertising market also changed in the second half of the seventeenth century. The near monopoly of new book publications among the advertisements was gradually eroded as the purveyors of other goods and services began to exploit the potential of the newspapers to reach new customers. Advertisements for language tutors and schoolmasters now vied with patent medicines and other goods and services for space and attention. For all that the book world continued to have a special place in newspaper advertising. Here we can draw a clear contrast with the newspaper market in that other fast developing commercial society, London. The sudden proliferation in newspapers publication in England in the last decade of the seventeenth century was

63 For the first year of publication, Lieshout's newspaper was entitled Extra-ordinaire of Middel-weeckse Courante.

64 Meininga did include advertisements in his newspapers, but for the most part only for his own publications.

65 See especially the case of Jan de Boer, explored in Jeroen Blaak, Literacy in Everyday Life. Reading and Writing in Early Modern Dutch Diaries (Leiden: Brill, 2009), pp. 189-264. 
sustained very largely by the enthusiastic embrace of paid advertising. ${ }^{66}$ But in England these advertised very largely goods and services, especially luxury consumables. There was far less room for book advertisements: this remained a special, characteristic feature of the Dutch newspapers.

The Dutch Republic created a very particular environment for a flourishing book market. A close network of large urban communities, each with its own active publishers, linked by efficient and swift internal communication through the canal network, created an ideal environment for both production and sales. One of the incidental revelations from the advertisements placed in the newspapers is the extent to which Amsterdam publishers made use of printers in other towns when local presses were otherwise engaged; stock could easily be moved back to Amsterdam by canal barges. ${ }^{67}$ The new state also offered optimum conditions for sales: nowhere else in Europe was there such a large pool of customers with sufficient disposable income to become active purchasers of books.

Publishers cultivated this market by placing advertisements in the newspapers: the importance of this new way of reaching customers can be seen in the speed with which it developed from an experimental novelty to an absolute staple of the business model of publishers and newspaper men alike. In the 1630 s and 1640 , over half of documented publishers and booksellers active in the Republic are known to have advertised in one or other of the Amsterdam papers. ${ }^{68}$ And here we must remember that we only have surviving copies of about $60 \%$ of the issues of the Courante uyt Italien and Tijdinghen uyt verscheyde Quartieren that must have been published during that time - and only ${ }^{10}-\mathbf{2 0} \%$ of the other Amsterdam newspapers. The advertisements in the missing papers would almost certainly increase this proportion further.

It has long been known that the first Dutch newspapers play an important role in the history of advertising; what has not fully been grasped until this point, is the important additional light they shed on the Dutch book world. A full enumeration of the books advertised in the newspapers of the Dutch Golden Age does not change our view of the market in any fundamental way:

66 See R.B. Walker, 'Advertising in London Newspapers, 1650-1750', Business History, 15 (1973) pp. 112-130. The older study of Blanche B. Elliott, A History of English Advertising (London: Batsford, 1962) is also still useful. See also Wiles, Freshest Advices.

67 For instance, the Verdediginge der Bewijs-redenen Conradi Victoris voor den Doop der Christen-kinderen advertised in CID no. 21 (26.05.1640), printed by Hans Paschiers van Wesbusch in Haarlem for Dirk Meyer in Amsterdam (USTC 1013644). USTC 1011177 represents the opposite case, printed in Amsterdam for a Rotterdam publisher.

68 See Der Weduwen, 'Booksellers, newspaper advertisements'. 
the books advertised come by and large from genres known to have been staples of the market. What it does show us is that this market was far richer and larger than can possibly be imagined from surviving copies alone. Books known from one or two editions can be shown to have been published in eight, nine or ten. The subtle range of formats in which publishers fed the market for staples of church life can also be demonstrated with new clarity. Taking the first fifty years of Dutch newspaper publication as a whole, the period between the establishment of the Tijdinghen uyt verscheyde Quartieren and the Courante uyt Italien and the sudden collapse of the De Witt regime in 1672, newspaper advertisements confirm the existence of something approaching a thousand books not otherwise known from surviving copies. This is a major advance in the understanding of this most sophisticated book market. 